\title{
Agricultural holdings with undefined boundaries, communal systems and counter-hegemonies: The persistence of peasantry in Argentina
}

\author{
Raúl G. Paz
}

Institute of Studies for Social Development (INDES)/National Council for Scientific and Technical Research (CONICET) and Faculty of Agronomy and Agroindustry, National University of Santiago del Estero, Santiago del Estero, Argentina

\section{Correspondence}

Raúl Paz, Institute of Studies for Social Development (INDES)/National Council for Scientific and Technical Research (CONICET), National University of Santiago del Estero, Avda. Belgrano (s) 2180-1 ${ }^{\circ}$ Piso. Santiago del Estero 4200, Argentina.

Email: pazraul@unse.edu.ar

\section{Funding information}

Scientific and Technological Research council of the School of Agronomy (UNSE), Grant/ Award Number: Project 23/A239; INDES/CONICET, Grant/Award Numbers: 2018-8-APN-DIR\#CONICET, project PIP $11220170100056 \mathrm{CO}$

\begin{abstract}
The presence of agricultural holdings with undefined boundaries (AHUBs) and their heterogeneous geographical distribution questions the supposed hegemony of agribusiness in Argentina. Given the lack of defined boundaries, these holdings generate a communal culture among dwellers, which is reflected in both the strategies of the use of commons and the initiatives for the defence of land in the conflicts between peasants and entrepreneurs. This article describes two counter-enclosure experiences that were generated and have developed on the bedrock of AHUBs and a communal matrix. Those defence strategies are employed by families that possess the land but have not title to it, being a defence tactic against attempts of eviction. AHUB not only is a new census category that allows us to enhance our knowledge of the rural world but also proposes modes of production that differ from those of the capitalist model, showing possible counter-hegemonic development alternatives that arise from the practices used in these holdings.
\end{abstract}

\section{KEYWORDS}

agrarian structure, counter-enclosure experiences, defence strategies, holdings with undefined boundaries, peasant communal system 


\section{1 | INTRODUCTION}

The Argentine humid Pampas, located in central Argentina, has historically been the region of the country where agrarian capitalism has been most intensely and dynamically expressed through a production scheme currently represented by agribusiness. In this context, in which the country is perceived as characterized by the hegemony of agribusiness and export-oriented production (Craviotti \& Gras, 2006; Gras, 2009), academic debate about the peasant issues has lost relevance, and its disappearance is now perceived as a fact.

However, the existence of 'another rural sector', located deep in the interior of Argentina, composed of subordinate agrarian social actors, such as the peasant sector, questions this supposed hegemony and raises the academic concern about old debates associated with the agrarian issue and persistence of peasants, the distancing from the markets, the appreciation of local resources, social agrarian movements and the generation of defensive behaviour or peasant resistance (Akram-Lodhi \& Kay, 2009; Boltvinik \& Mann, 2016; Paz \& Jara, 2014; van der Ploeg, 2018).

The method used in the 1988 National Agricultural Census (1988 NAC) revealed a particular type of agricultural holding that had not been identified until then and that is very frequent in some Argentine regions. For the 1988 NAC and the subsequent national agricultural censuses (2002 and 2008 NACs), two types of questionnaires were used: one for the units with defined boundaries and a special questionnaire for agricultural holdings with undefined boundaries (AHUBs), which does not record the size (in hectares) of the land occupied by that agricultural holding. Using this methodological perspective, the 1988 NAC identified an Argentine agrarian structure composed of 421,221 agricultural holdings, of which nearly $11 \%$ are included in the AHUB category. Of all the AHUBs, $70 \%$ are concentrated in the north-western (NWA) and north-eastern (NEA) regions of Argentina, and less than $2 \%$ are in the Pampas region.

The presence of the AHUBs and their heterogeneous spatial distribution encouraged some reflections that are still valid (Paz \& Jara, 2014). First, the lack of AHUBs reflects a more dynamic capitalist development, whereas the strong presence of these holdings denotes a slower or weaker capitalist penetration (Paz, 2011). Second, AHUBs are associated with a type of poor and marginal agrarian social actor (Giberti, 1993) that is strongly related to the condition of campesino ocupante (peasant as occupier) (Paz, 2006), campesino con ánimo de dueño (peasant with intent to own) (de Dios, 2012) or puestero criollo (peasant who lives in a land portion granted by the large estate owner; in return, he raises animals, mainly cattle, and works for the land owner) (Camardelli, 2005). Irregularities in property titles, which hinder the formal and secure access to land, are associated with rural poverty in the continent (AkramLodhi, Borras, \& Kay, 2007).

Those agricultural holdings, which are involved in land tenure conflicts, are usually termed 'occupancies', in reference to a heterogeneous and complex group of more or less precarious forms of land tenure. This group includes occupancy of private and public lands, communal lands, indigenous communities and national protected areas, among others (González, 2000; Slutzky, 2007). Precarious land tenure, the lack of property titles and the processes related to the expansion of the agricultural frontier have triggered several conflicts that proliferated between rural dwellers and different economic stakeholders ${ }^{1}$ (Barbetta, 2009; de Dios, 2012; Paz, Lipshitz, Zerda, \& Tiedeman, 2015) as well as strong processes of dispossession (Cáceres, 2015; Harvey, 2005).

AHUB is not just a new census category that allows us to expand the knowledge of the rural world. The concept of AHUB also proposes modes of production different from those of the capitalist model, showing possible development alternatives that may arise from the practices used in these holdings (Santos de Sousa, 2006; Santos de Sousa \& Rodríguez, 2011). Because they do not have definite boundaries, these agricultural units are regarded as communal land by their dwellers, which is reflected both in the strategies for using both commons and labour. There is a communal logic that has been displayed over time and that is materialized in the past and present routine practices conducted by peasants. This communal culture, as expressed by Farberman (2016), is not exclusive to indigenous

${ }^{1}$ A study conducted by the Observatorio de Derechos Humanos de las Comunidades Campesinas (Observatory for Human Rights of Peasant Community) of the Under secretariat for Human Rights of Santiago del Estero province indicated that, between 2004 and 2011 , about 420 claims related to land issues were recorded, amounting to 475,101 ha. 
communities. Besides having solid historical records in the Iberian culture (Beltrán Tapia, 2014), communal culture was also displayed by other actors in different collective agricultural practices.

AHUB and absence of private property, mainly of land, are strongly associated; however, in some cases, this phenomenon also applies to animals, tools and infrastructure, because they are part of the community. The possession of commons is not a suitable bedrock for applying the practices of capitalism, while private property is one of the main pillars on which capitalism can fully develop (Marx, 1984; Marx \& Hobsbawm, 1987; Smith, 1997). As mentioned by Wood $(2002,2009)$ in reference to market imperatives, there is a natural tendency of capitalism to pay with money for labour, exchange goods and obtain profits, and these facts cannot be considered without the commodification of land (Polanyi, 2011). This lack of private property precisely formulates a different form of land appropriation and proposes the idea of counter-hegemony, which suggests the existence of communal matrices with other logics of production. Those logics come into tension and lead us to suppose that there is another mode of producing that does not necessarily have to respond to those market imperatives (Holloway, 2011). This logic of production by the communal systems cannot be framed within the logic of capitalism, because capital gradually loses its own centrality, and its disciplinary role in the productive process progressively melts away (Harvey, 2014; Paz, 2017).

The agrarian structure in the NWA and NEA regions has an important presence of AHUBs, with communal system playing a key role. These units are far from being considered as confined to history; indeed, they are a source of several experiences that have arisen as a response to land conflicts typical of the agricultural structure in Santiago del Estero, which have led to continuous evictions of peasants. As stated by Federici in an interview made by Linsalata and Navarro (2014), it is no accident that processes of resistance to land expropriation and processes that are counter-hegemonic to capitalism are detected in those areas of the world where community relationships are more concentrated.

This article analyses two communal experiences that arose from land conflict due to agribusiness and the expansion of the agricultural frontier, two factors that attempt to encroach onto AHUBs. One of the cases refers to communal livestock enclosures in the locality of El Hoyo (Figueroa Department). The other case consists of the formation of the Reserva Campesina (Peasant Reserve) in Ojo de Agua. Both experiences depict an interesting case of counter-enclosure (Borras \& Franco, 2010) of natural commons to avoid their privatization and commodification.

The article is divided into four sections. The first section analyses the current agrarian structure in Santiago del Estero and provides a detailed quantification of AHUBs. The second section describes the AHUBs, in an attempt to understand their formation through historical processes, and provides some aspects of the communal practices that have been developed in those units over time. The third section presents the two cases, and finally, the fourth section presents the nature of counter-hegemony, from a political economy perspective, and the possible changes of alternative development based on the communal matrices generated in these holdings.

\section{I AGRARIAN STRUCTURE AND AGRICULTURAL HOLDINGS WITH UNDEFINED BOUNDARIES}

Obschatko, Foti, and Román (2007) reported the presence of small-scale producers in Argentina based on the 2002 National Agricultural Census (2002 NAC). Thus, 218,868 small-scale holdings were identified $(65.6 \%$ of the total of the country), covering $13.5 \%$ (23,196,642 ha) of the total area at that time, with three types of small-scale producers, depending on the degree of capitalization (T1: capitalized, accounting for $21 \%$ of the total of small-scale producers; T2: intermediate, with 27\%, and T3: subsistence, with 52\%; see Table 1).

However, their distribution is not homogeneous in the national territory. With the aim of understanding the irregular forms of capitalist penetration in the Argentine agricultural sector, here we present a brief description of the Pampas and NWA regions as two contrasting regional spaces. Whereas the Pampas region, located in the most fertile plains in the centre of the country, is the area of most dynamic capitalist development in the national territory, where economic and social development can parallel that typical of similar areas in developed central economies 
TAB LE 1 Number of agricultural holdings (AHs) and average area (ha) for the different types of small-scale producers in the Pampas and NWA regions

\begin{tabular}{|c|c|c|c|c|c|c|c|c|c|}
\hline \multirow[b]{2}{*}{ Region } & \multicolumn{3}{|c|}{ Type 1 (capitalized) } & \multicolumn{3}{|c|}{ Type 2 (intermediate) } & \multicolumn{3}{|c|}{ Type 3 (subsistence) } \\
\hline & AHs & $\%$ & Average area & AHs & $\%$ & Average area & AHs & $\%$ & Average area \\
\hline Pampas & 21,760 & 36 & 236 & 20,649 & 35 & 113 & 16.332 & 29 & 72 \\
\hline NWA & 4,778 & 8 & 162 & 10,722 & 20 & 85 & 39.184 & 72 & 37 \\
\hline Country & 47,032 & 21 & 242 & 58,602 & 27 & 107 & 113.234 & 52 & 52 \\
\hline
\end{tabular}

Source: Obschatko et al. (2007). Extracted from Paz and Jara (2014).

(Manzanal, 1995), the NWA, ${ }^{2}$ on the other extreme, shows a weaker or more limited capitalist development, with scarce capitalism penetration and strong presence of agricultural holdings of peasants and low levels of capitalization.

The analysis of the data of the three types of small-scale producers reveals the strong presence of Types 1 and 2 for the Pampas region, whereas Type 3 (the poorest type of the agricultural sector and the one that includes the AHUBs) has a strong prevalence in the NWA region. These data, though general, not only denote the magnitude and characteristics of small-scale production in these regions but also explain the particular inequality of development in the Argentine agricultural sector: the high proportion of more highly capitalized family farmers (Types 1 and 2) in the Pampas region ${ }^{3}$ and the strong presence of subsistence peasants ${ }^{4}$ (Type 3 ) in the NWA region.

The NWA region holds great agroecological and socio-economic diversity, which hinders generalizations; however, a common characteristic of the region is the lower capitalist development than in the Pampas and the significant persistence of small agricultural holdings that are in tension with the latifundio (large land holdings). The presence of AHUBs contributes to this tension; indeed, NWA holds 24,806 AHUBs, ${ }^{5}$ accounting for $37 \%$ of the holdings, whereas the Pampas region only holds 766 (less than 1\%), according to the 2002 NAC. The composition of agricultural social actors and their persistence provide the academia with a great laboratory to think of the logics of peasants, the distancing from the market, the appreciation of the local resources, agricultural social movements and the building of defence or resistance behaviour patterns as well as of new designs in the production processes that are in line with agro-ecology and food sovereignty.

In the province of Santiago del Estero, where the case studies are located, data from the 2002 NAC indicate 20,949 agricultural holdings, of which 10,830 have defined boundaries and cover 5,393,632 ha. The remaining holdings, that is, 10,119, are AHUDs and are distributed across approximately a 7,000,000-ha area ${ }^{6}$ (Paz et al., 2015). The agricultural structure in Santiago del Estero is characterized by a marked concentration and polarization of land property, with $63 \%$ of holdings smaller than 100 ha concentrating only $3 \%$ of the total land. This is also the Argentine province with one of the highest percentages of peasant units (67.80\%) and of precarious land tenure, with land holdings lacking a legal title; see Table 2.

\footnotetext{
${ }^{2}$ The NEA region and part of Cuyo region have similar characteristics to those of NWA. The Patagonian region has been recently incorporated to the national economic system and combines advanced and traditional capitalist modes, with no connection between them (Manzanal, 1995).

${ }^{3}$ For further details of the quantification of the small-scale producers sector, see Paz and Jara (2014) and Paz (2011).

${ }^{4}$ 'Subsistence peasants' category is not defined by the area of the farm unit; rather, it is defined by the availability of resources, which is not enough to live solely on their own production and therefore have to resort to other subsistence strategies, such as temporary jobs or social assistance plans. This sector is strongly related to structural poverty and marginality conditions.

${ }^{5}$ As mentioned above, the agrarian structure of the NWA is composed of $37 \%$ of AHUBs and $63 \%$ of holdings with defined boundaries. Within the NWA, the agrarian structure of Santiago del Estero province consists of $49 \%$ of AHUBs and $51 \%$ of holdings with defined boundaries, whereas AHUBs amount to $55 \%$ in Jujuy, $46 \%$ in Salta, $28 \%$ in La Rioja and $27 \%$ in Catamarca.

${ }^{6}$ Agricultural holdings with undefined boundaries are not fenced nor have their size been measured; this situation is very common among peasants who only demarcate boundaries for agricultural activities and animal grazing in the forest using branches. The most common land tenure regime is land possession of private or fiscal land, with possessors having no legal titles or deeds. It is usual to hear elder peasants saying: 'I was born and raised in this place, where my parents stayed, but we do not have the title deeds' (de Dios, 2012). Estimation made from data obtained by digital photointerpretation (Mariot, 2005)
} 
TAB LE 2 Number of peasant holdings, by type of boundaries (defined or undefined), National Agricultural Censuses (NACs) 1988 and 2002

\begin{tabular}{lrr} 
& \multicolumn{1}{c}{ Total holdings } \\
\cline { 2 - 3 } Santiago del Estero & 1988 NAC & 2002 NAC \\
\hline Total agricultural holdings (AHs) & 21,122 & 20,949 \\
\hline AHs of peasants with defined boundaries & 4,992 & 4,096 \\
\hline AHs of peasants with undefined boundaries & 9,329 & 10,119 \\
\hline Total AHs of peasants & 14,321 & 14,215 \\
\hline$\%$ AHs of peasants with respect to the total & 67.80 & 67.80 \\
\hline
\end{tabular}

Source: Paz (2013).

Note. El Minifundio en la Argentina (Caracciolo Basco \& Rodríguez Sánchez, 1978) is one of the pioneer works in attempting to quantify this type of holdings. The document considers the minifundios (small holdings of peasants) as holdings smaller than 10 ha in area, for those located in an irrigation area, and less than 100 ha for those located in rainfed areas.

One of the main characteristics of this region is the vast territory of more than 7,000,000 ha lacking legal regulation. AHUBs are scattered across those lands, with ownership coexisting with possession ${ }^{7}$ as a legal right; this aspect creates a line of conflict between businesspeople and peasants.

Any territory characterized by adverse climatic conditions, a hostile but resource-abundant forest environment (providing honey, wax, wood, wild fauna, forest fruits, forage, dye and medicinal plants), vast land extensions and fragile agro-ecological conditions for agricultural production requires a social structure with a complex demographic network and division of roles according to gender and age oriented to cover their own reproduction. In other words, the basis for the functioning of these social and production systems in the open forest, both in the past and in the present, has been the constant and intense use of human energy, both in the gathering ${ }^{8}$ and production processes, which very often exceed the individual efforts and the family environment and are undertaken from a communal perspective (Farberman, 2016; Palomeque, 1992; Paz, Rodríguez, \& Jara, 2018).

The persistence of AHUBs is due not only to the existence of a retarded capitalism in the region but also to other factors. In fact, the existence of these holdings dates back to the onset of the agricultural structure configuration, and their permanence is explained by the social-spatial marginality situation of the areas where they are located and the scarce capital penetration. This phenomenon is reflected in seasonal migration processes, a significant production for own consumption and a communal culture; in the prevalence of forms of possession, which are different from those of the private appropriation; in the irregular legal situation of land; in the presence of an informal commercialization system; and in the prevalence of a low productive livestock rearing system, which is a consequence of an extensive and traditional production with scarce or null incorporation of technology, adapted to the few natural forage resources present in this type of ecosystems.

A great number of AHUBs are located in the northern area of the province, where large forest areas still remain. The permanence of peasants is made possible by these land areas associated with a considerable livestock production system along with a noncommodification process and some degree of geographical isolation (Paz, 2006). Such social and productive strategies are usually based on resources provided by the forests, such as fire wood, as well as the forage supply for livestock development. The 2002 NAC indicated for NWA region

\footnotetext{
${ }^{7}$ Section 1909 of the new Civil and Commercial Code of Argentina recognizes that there is possession 'when a person, for himself or for another, exercises a power in fact over a thing, behaving as a holder of a real right, whether this is the case or not'. Likewise, Section 1928 recognizes as acts of possession 'their cultivation, the gathering of fruits, their demarcation or impression of material signs, improvements, exclusion of third parties and, in general, their occupancy in any manner whatsoever' (our translation).

${ }^{8}$ For example, algarrobo (Prosopis alba) fruit collection, an activity that was recorded from the pre-Hispanic era to mid-20th century, involved numerous people who, during summer, went into the deep interior of the forest to gather the pods. The 'tako pallana' festivity is documented in the 1921 National Folklore Survey.
} 
that $20 \%$ of a total of $1,044,169$ cattle belong to the AHUBs; these holdings also concentrate $65 \%$ of sheep, $63 \%$ of goats, $54 \%$ of pig and $49 \%$ of horses. The important numbers of livestock and the vast extensions where they can move around are key elements for the maintenance of these systems.

The northern portion of the province is a geographical space with presence of agricultural companies that are involved in the expansion of the agricultural frontier initiated in the early 1970s and that still continues (Román \& González, 2016). At present, there is a constant confrontation, tension and dialectic adaptation between the production methods of peasants and the ubiquitous and dominant willing of agribusiness to contest and subordinate the production model of the AHUBs.

\section{I AGRARIAN STRUCTURE, AHUBS AND PEASANTIZATION PROCESSES: A HISTORICAL APPROACH}

The agrarian structure expresses the power relationships and disputes for the occupation of the space between individuals with different logics of territorialization. The contextualization of the agrarian structure responds to longterm variables and more recent dynamics, such as the expansion of the agricultural frontier, land foreignization and land grabbing (Paz \& Jara, 2013). Indeed, the analysis of the present configuration can be understood concomitantly with different past processes that should be considered. Before the Spanish conquest, the population was settled in the current Santiago del Estero territory, between Dulce and Salado rivers, known mainly as an area of establishment of Lule and Tonocoté peoples. Lule people were identified as nomadic hunters, whereas the latter were described as sedentary farmers (Farberman, 2016). Below, we present three periods that suggest the bases on which AHUBs were founded (Paz, Jara, \& Wald, 2019).

The first period starts with the Spanish conquest and colonization; during this period, the communal lands of the native populations were subjected to different forms of private appropriation, such as mercedes reales ${ }^{9}$ and encomiendas. This process did not mean the dissolution of the communal land management practices (Banzato \& Rossi, 2010); according to Farberman (2018), there were three types of indivisible property: the mayorazgo, the indigenous community and the communal lands. These types of possession are typical of arid environments, where collective agricultural practices associated with the management of land, forest and water were conducted by a group of people joint by family relationships.

The second period was characterized by the replacement of encomiendas with reducciones during the 17th century and then with small forts (military outposts) and with large estates late in the 18th century. During this process, forms of space occupation by criollos (term coined in colonial times to refer to people of Spanish descent born in Latin America) in vast land areas with undefined boundaries were gradually defined. This social relationship present in the large estates is termed agregados (literally meaning 'attached' people) and describes the presence of peasants and indigenous peoples within a single estancia with the aim of providing labour, especially during harvest periods. There are evidences that, during that period, land acquired more value, in monetary terms, with increasing number of people living there who could perform agricultural activities under the influence and care of the owner or patron (Farberman, 2018).

The third period starts in the second half of the 19th century, within the frame of the formation of the national and provincial states. Given the integration to the capitalist market, the latifundia were consolidated by dispossessing

\footnotetext{
${ }^{9}$ The Royal land grant (Merced de la Tierra) is a legal Iberian institution that originated between the 15 th and 16 th centuries. It used to refer to a royal 'donation' (by the Crown) of real estate and titles in exchange of a service. During the earliest decades of the Spanish conquest, the kings made land grants with the aim of fostering the effective occupation of the territory by the conquerors, founders or settlers. In general, each settler received an urban plot and a larger land plot in the areas adjacent to the village for livestock production holdings (large estates or estancias) or for cropping. In turn, the encomienda was an institution by which a person (the encomendero) was assigned a group of indigenous people who were obliged to pay tribute in labour or some other kind of tribute. In all cases, the encomendero was obliged to foster and pay for the Cristian education of those peoples. In other words, the encomienda was a forced labour system for aboriginal people to the benefit of the encomenderos.
} 
peasants and indigenous populations of their lands. By mid-1930s, obrajes ${ }^{10}$ (timber yard) were implemented in the province, which entailed the development of a mode of production and territory occupation in the forest of Santiago del Estero that was associated with railroad expansion in the country; this phenomenon involved the investment of foreign capitals in timber species exploitation, especially Schinopsis balansae, commonly known as quebracho colorado (Dargoltz, 2003) in the forests of Santiago del Estero. Tasso (2005: p. 126) indicates that both the large estate and the obraje generated 'a rigid social system that strengthened the old vassalage under capitalist forms and consolidated of patronal-type political styles' (our translation). This social configuration, which articulates servitude systems and integration to the market economy through primary production, was the basis for the agrarian structure in Santiago del Estero.

By the mid-12th century, logging was no longer profitable, and the obrajes were dismantled, leaving a deforested area and unemployment of the workforce that had been absorbed by the capitalist logging enterprises. Although several jobless people decided to migrate, some of those who had been working as woodcutters stayed in these lands, developing reproduction strategies associated with agricultural production, thereby giving rise to repeasantization processes; however, their land possessions were not regulated by the Civil Code.

It should be noted that the gradual development of the agrarian structure of Santiago del Estero was shaped by an overlap of property and possession rights, as well as of depeasantization and peasantization processes; this phenomenon becomes evident in the presence of the AHUBs. Such situation is a historical construction that has been operating for centuries of coexistence of capitalist and precapitalist forms; although those forms are antagonistic at present, they were functional at different moments. Thus, this 18th century tradition of estancias of having agregados $^{11}$ (peasantization processes) since colonial times for more than two centuries was considered positive for agrarian development but turned into a problem for the current capitalist companies and agribusiness, which try to keep peasants away from the land.

The vulnerability of these peasants who hold no titles to the lands and who were subjected to dispossession was intensified during the 1960s, when important investors focused on fiscal land of Santiago del Estero portion of the Chaco to invest in cotton production. These situations of agrarian conflicts associated with land tenure have spread as part of the dynamics of contemporary processes, such as the expansion of the agricultural frontier, foreignization and land grabbing ${ }^{12}$ (Soto Baquero \& Gómez, 2012; McMichael, 2013; Akram-Lodhi \& Kay, 2009; Paz \& Jara, 2013; Paz et al., 2015), key aspects to understand the present agrarian structure, but that are beyond the scope of this article.

\section{4 | COUNTER-ENCLOSURE EXPERIENCES}

The two cases have some aspects in common, because both originated and developed on the basis of AHUBs and a communal-type socio-productive matrix. They are defence initiatives against conflicts for land and material or

\footnotetext{
${ }^{10}$ The obraje was a production system of the Gran Chaco region during the late 19th century and early 20th century. The obrajes consisted of facilities for large-scale logging of quebracho colorado forests. Obrajes were characterized by being temporary, with their permanence in a particular site depending on the abundance and quality of quebracho trees. This economic activity was a form of production that was well integrated into global capitalism and was based on a system of recruitment and retention of a highly vulnerable workforce. The fate of the workers was at the mercy of the contractor, the foreman or the employer. This work involved the entire family, with children and women helping loggers in cleaning tasks, and other household activities, such as laundry, caring for young children and selling food. The workers' dependency on the employer for the supply of goods created a captive market where workers were permanently indebted.

${ }^{11}$ Lorenzo Fazio (1889: p. 283) associated agregaduría with the large estates in the following terms: 'We are not used to renting lands; few types of these operations are known; rather, it can be stated that the owners of large land areas allow poor people to settle in and occupy their fields, forming small estancias and puestos. In Santiago del Estero countryside, the term agregados refers to these poor families that build their houses on other people's lands and compensate for the good will of the owner by offering their personal labour; agregados were paid a low wage by the owner when the latter needed them for some important works (extracted from Farberman, 2018).

${ }^{12}$ For Akram-Lodhi (2012: p. 125), land grabbing refers to land deals that comprise 'large-scale acquisition through buying, leasing or otherwise accessing productively used or potentially arable farmland by corporate investors to produce food and nonfood crops, in order either to boost supply for domestic and/or world markets or obtain a favourable financial return on an investment.' Although there is no consensus on what land grabbing is, the use of this concept entails important political functions inasmuch as it connotes power relations and historical substance to current disputes over land. Effectively, it is a concept in evolution (Borras, Kay, Gómez, \& Wilkinson, 2012; Paz et al., 2019).
} 
symbolic enclosures established by families that possessed the lands but had not title, being a defence tactic against attempts of dispossession. Those conflicts arose due to the overlap of property rights claimed by business people when arriving at the place and the historical possession by dwellers (Wald, 2016). Another aspect is that those initiatives are based on the reproduction of long-standing communal practices of resource use and management. Possessors have historically made a shared use of commons, such as land, forest and water, to develop their social and production practices. Importantly, those defence strategies are recreated in combination with and supported by the state, through the articulation and intervention of organizations and national and provincial state agents.

The locations of these experiences within the province are indicated in the map, as well as the geographical location of Santiago del Estero province in the national territory (Figure 1).

\section{1 | The case of El Hoyo: wire fence, produce and resist}

The case refers to the community livestock enclosures of the locality of EL Hoyo (Figueroa Department), which covers more than 10,000 ha of shared communal land, and where a total of 40 families are settled (Gómez, Jara, Díaz Habra, \& Villalba, 2018). El Hoyo is one of the 19 cases of community livestock enclosures that are concentrated in Figueroa and Moreno Departments of Santiago del Estero province, the departments most widely affected by the expansion of the agricultural frontier associated with the agribusiness model development (Paz et al., 2015). There is no accurate calculation of land hectares, number of animals or infrastructure involved in the 19 enclosures ${ }^{13}$; however, according to the systematization of four enclosures performed by Gómez, Villalba, and Tort (2018), they cover more than 25,000 ha and involve 110 families. Paz, Rodríguez, and Jara (2018) estimated that these 19 enclosures would involve more than 250,000 ha and 400 families.

This experience was originated when a company from another province advanced into the lands claiming ownership, fencing the land that had been used for livestock grazing by these families ${ }^{14}$ and filing criminal complaints for usurpation. As a response, there was a process of counter-enclosure, a term used by Borras \& Franco (2012) as a counterpart of the capitalist enclosures, as termed by Marx. Enclosures make reference to processes of physical and legal violence through enclosure acts, which destroyed the traditional forms of collective land use in England in the 17th century, when many peasants were evicted from their lands; consequently, they were no longer direct producers. Thus, land is no longer thought of as a way of living; instead, it is incorporated into production processes as a production factor and is ruled by market laws (Polanyi, 2011). By contrast, counter-enclosures are understood as manifestations of insubordination and resistance to dispossession of commons by capital, whereby control practices of those commons are developed by establishing physical or institutional fences around certain resources to ensure that a given population has access to those resources (Gómez, Jara, et al., 2018). Those communal appropriation relationships are supported by a network of social relationships of dwellers based on their neighbour and family bonds. This social network also provides the basis for practices of collaborative work organization; those practices have been historically applied in this community. For example, these practices are not ruled by the price of labour in the market; that is, the category of salary gradually disappears, and reciprocity logic in reproduction of communal work prevails. The community work days that involve several dwellers to perform maintenance tasks of the common water reservoir include practices characterized by an underlying logic of reciprocity in their relationships. This implies that

\footnotetext{
${ }^{13}$ Here, it is necessary to make a digression to understand this term. Community enclosures arise approximately in 2004 within the frame of the national government of Cristina Kirchner, where a national-popular project was already implemented with institutional support, including the Secretariat of Rural Development and Family Agriculture (Lapegna, 2018). The technical-professional teams of the university had been working and making contributions in this line within the frame of institutional agreements. Then, during the neoliberal government of Mauricio Macri in 2015, this secretariat was downgraded to an under secretariat, which triggered a human and financial resources dismantling process. As a mere example, of the 110 technicians who worked in the provincial office, approximately 25 remain today, and no institutional agreements have been renewed. When we requested information about the community enclosures, they manifested that there was no information and did not provide the data for systematization.

${ }^{14}$ Interestingly, this experience served as an example to other experiences. To the northwest of Moreno Department, adjacent to locality of El Hoyo is the locality of El Puesto, where some 30 families formed a community enclosure of 5,500 ha. While the inhabitants of this locality were not involved in any land conflict, the permanent attempts of eviction in nearby localities prompted them to delimit the common use lands to reaffirm their possession.
} 


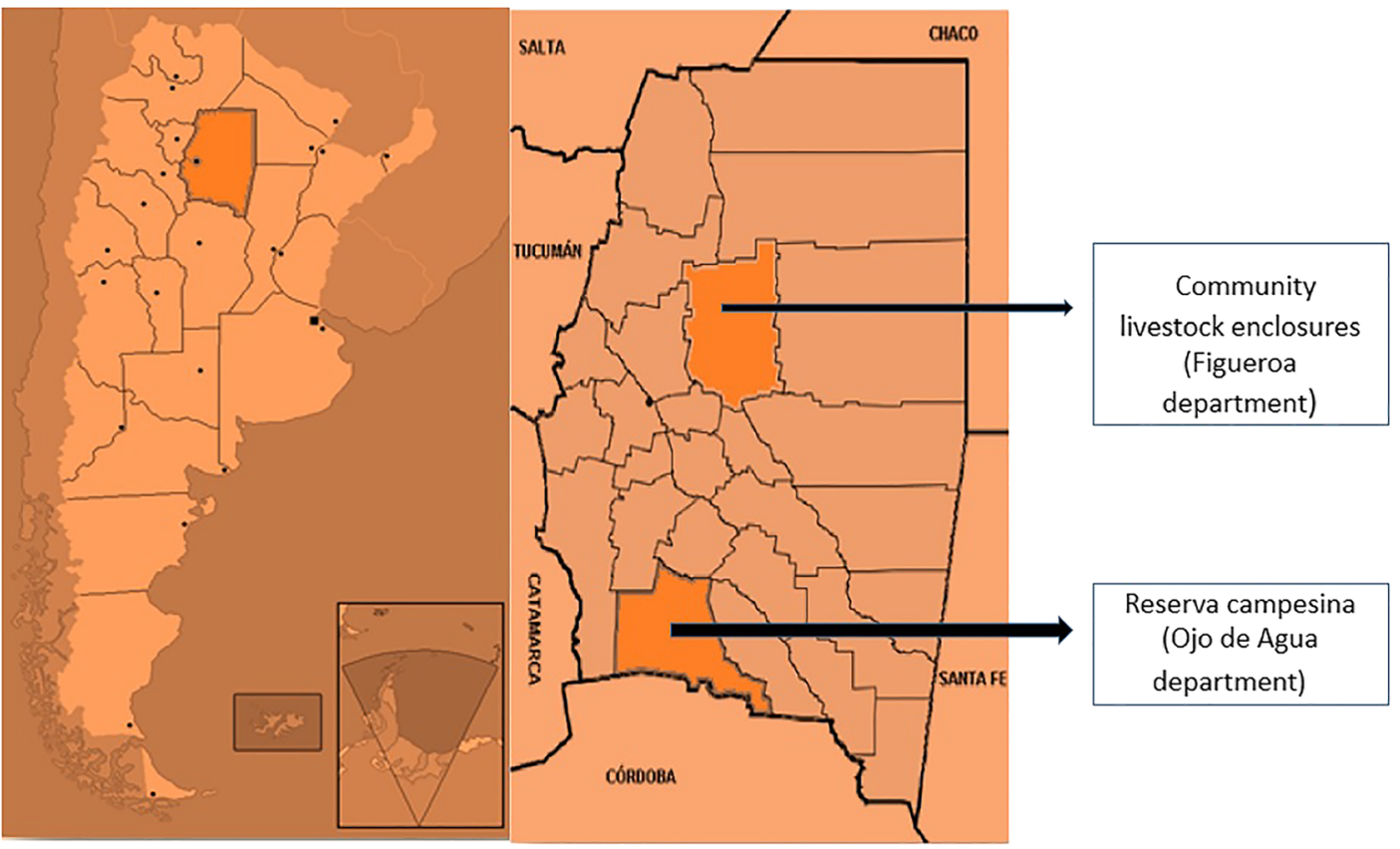

FIGURE 1 Geographical location of the two cases

the provision of work energy, though voluntary, is supposed to receive a nonmonetary counter-provision in other circumstances.

Thus, land defence was first implemented through counter-enclosure, based on production and the ancestral logic rooted in the community, which consisted mainly of cattle and goat breeding and the shared use of the forest, where the main activities are timber and charcoal extraction. The challenge was to improve production using a technical-productive dimension and another dimension involving organization and administration. The former consisted of the construction of pens and reservoir works to store rainwater, incorporation of pastures using a silvopastoral management based on the forage dynamics of the forest, animal genetic breeding, among others. The latter dimension is related to organization and management of common resources based on agreements and regulations within the community.

Most of the decisions on the use, administration, control and production, such as preservation and defence of all the communal goods, are discussed and resolved in community meetings with the participation of dwellers and government agents. The intervention practices of state agents were key for the implementation of community livestock enclosures. At the beginning, technicians from the National Institute for Agricultural Technology (INTA) provided information about land possession rights and shared that information with other peasants that were living conflict situations similar to those in El Hoyo community. There were also some institutions that represented peasants and indigenous peoples in their struggle for land, such as Mesas de Tierras ${ }^{15}$ (Land Boards) and DUFINOC (United Delegates of Figueroa Norte Eleven Commissions), which were involved in the dissemination and appropriation of the discourse about land possession rights. Finally, the Secretariat of Family Agriculture (former Agricultural Social Programme) provided technical and financial assistance to undertake productive activities that allowed the use of the intrinsic potential of forest biodiversity and ecosystem services, an already present livestock raising culture and pre-

\footnotetext{
${ }^{15}$ Mesas de Tierras (Land Boards) are organizations whose origin is related to the intervention of the social pastoral activity of the Catholic Church in rural localities; at present, besides representatives of basic ecclesiastic communities, they are composed of government organizations that perform rural extension activities, as well as representatives of the Movimiento Campesino (Peasant Movement) of Santiago del Estero. The Mesa de Tierra of Figueroa emerged in 2003 in the context of a number of conflicts due to threats of eviction of peasants from the lands they occupied and is composed of representatives of different localities of the Figueroa and Moreno departments.
} 
existing community work institutions (Gómez, Villalba, \& Tort, 2018). In this sense, community relationships were mediated by institutional interventions, especially in the application of state policies, which makes us think of the capacity of the state to build new forms of production management and governance of commons in rural environments (García Linera, 2010; Patzi Paco, 2004).

In support of possession in terms of civil rights, attempts were made to make the conflict visible by increasing livestock production activity and implementing production improvements. The slogan in the enclosures was 'fence, produce, resist', with the main strategy being the establishment of perimeter wire fencing and the consolidation of production oriented to the markets as forms of resistance. This slogan, as well as that used for the Reserva Campesina case, is still not rooted in both communities but is gradually being adopted as researchers and the community interact, especially scholars that have been conducting several systematization works within the frame of their research projects and doctoral thesis works at the Institute for Social Development Studies (INDES) at the National University of Santiago del Estero (UNSE). The basis of those slogans was the motto 'occupy, resist and produce', which represents Brazil's Landless Workers' Movement since 1984 and that installs the idea of the occupation of the lands by families, resisting and producing food in them.

\subsection{The case of the Reserva Campesina: Legally fence, institutionalize-make visible and resist}

The second experience corresponds to the Reseva Campesina, located in Ojo de Agua department, which covers about 25,000 ha and includes several localities where about 200 families live. Its production potential is not like that of El Hoyo, because in the Reserve, production is subsistence oriented and includes rearing of goat, cattle and chicken for subsistence purposes. ${ }^{16}$ While goat production is one of the principal economic activities, several peasants make handicrafts, especially of leather and wool ${ }^{17}$; they are also involved in seasonal migratory processes (Diaz Habra \& Jara, 2018).

This is a paradigmatic case, because it shows the land property/possession overlap and its complexity in a long historical process. An entrepreneur from Buenos Aires, a member of the Sociedad Rural Argentina (organization that represents the interests of large-scale land holders from the Humid Pampas) purchased fiscal lands, where peasants lived, from the provincial government. The entrepreneur took up a mortgage on those lands to invest in the fields in the Pampas region. After some time, and given that the mortgage was not paid off, those lands were foreclosed by the credit institution, and the plots were transferred to a foreign entrepreneur through an auction in the 1960s. When he found that there were possessors in 'his lands', the foreign entrepreneur demanded the payment of a rent for occupying the lands to the families settled there who accepted that agreement due to their lack of knowledge about possession rights. In 1990, this entrepreneur sold part of the land and started to implement eviction actions. The turning point of the conflicts in the area was in 2003, when a group of entrepreneurs fenced the common water reservoirs, restricting the passage of dwellers and their access to water (Diaz Habra \& Jara, 2018). In this case, dispossession of peasants was not caused by the expansion of the agricultural frontier but, rather, by economic agents that, with the connivance of lawyers, notary publics and financial actors, identified the suitable conditions for shady deals with the lands.

The Reserva Campesina was designed in response to the eviction threat. It was another form of counter-enclosure, differing from the community livestock enclosures in that there was no perimeter fencing; instead, the legal instruments in force ${ }^{18}$ were used, and by displaying the existing social relations (e.g., institutional relations through

\footnotetext{
${ }^{16}$ According to estimates made by local extension technicians, a typical family has, on average, approximately 70 goats, 20 cows and 40 hens.

${ }^{17}$ In February, the Festival Nacional del Artesano is conducted in Villa Ojo de Agua. That festival gathers visitors from different parts of the country, being an opportunity for selling handicrafts.

${ }^{18}$ In Argentina, unlike in Colombia, there is no legal concept of Reserva Campesina (Peasant Reserve). The reform of the National Civil and Commercial Code did also not incorporate the communal property of peasants (unlike the recognition made to indigenous communities). The Act 26331 of 2007 (National Act of Minimum Budgets for Environmental Protection of Native Forests) was adapted and used for those purposes.
} 
agreements), it was possible to restrict access of foreign agents and to allow the effective access and use of land by peasants (Diaz Habra \& Jara, 2018; Peluso \& Lund, 2011).

National Act 26331, which deals with territorial zoning of native forests, provides the opportunity to think of this experience as a project that aims to build a protected space for both natural resources and basic rights of rural families who have ancestrally inhabited this place, even protecting the provincial patrimony. The defence of land also becomes the defence for land, because an idea of defence also of nature and culture is gradually instilled, valuing the archaeological and cave painting sites present inside the reserve.

Based on this idea, in 2012, the civil organization Mesa de Tierras de Ojo de Agua (Ojo de Agua Land Board) was created, with the participation of the affected peasants and technicians from other government institutions, such as the Registry of Possessors and Land Observatory, both created by the provincial government, National Parks and Protected Areas, the Institutional Relationships of the Chief Cabinet Office, the University (UNSE), among others. Interestingly, the relationship between the Reserve and actors of the UNSE has encouraged cooperation for the management of the cultural heritage and has promoted research works in the Reserve, because there are sites of great historical and archaeological value, like the cave paintings. The INDES and the Institute of Anthropology at UNSE also participate in the organization, attempting to systematize the experience.

The strategy is 'fence, institutionalize-make visible and resist', being a more symbolic enclosure from a legal perspective, with the construction of an institutional architecture that is strongly linked to state agencies and instilling the idea of defence for and of land. Incorporating the defence of cultural heritage places the conflict in a higher category, one that exceeds the local problems, involving the provincial level, thereby making the conflict visible from other perspectives.

Although the Reserva Campesina has been recognized by the state, the problem has still not been fully resolved, because the category of Reserva Campesina or community property of peasants does not exist in the Argentine legal system. However, the process of appropriation or adaptation to the rules and public policies in force has allowed the local dwellers, in coordination with state agents, to strengthen the social links, create bonds and face common challenges, trying to preserve the conditions that ensure the collective permanence.

\section{5 | COMMUNAL MATRICES AND COUNTER-HEGEMONY}

In an attempt to understand the counter-hegemonic character of both experiences, it is interesting to address AHUBs from conceptual frames that allow their interpretation in terms of their economic and social behaviour in a specific natural scenario. From this perspective, AHUBs can be considered a communal system with very specific characteristics, where there is a logic of community land possession and, consequently, of community resource use. Community land possession gave rise to a social form of production of material goods, in which the work process has a specific technical-organization content (García Linera, 2010; Patzi Paco, 2004). The system of communal property rights itself is the basis of the counter-hegemonic processes and highlights another form of producing value.

The current extensive portions of unfenced land (absence of enclosures) show a natural setting rich in plant and animal species, which can provide those populations with the most basic means of life if an immediate or direct work process is applied. Activities such as collection, hunting, fishing and grazing have been the oldest ways of obtaining material goods necessary for life, which are still used as production forms with particular technical and organization characteristics. In the AHUBs, part of the production that provides the material means of life and means of work is created by nature itself and used directly with a small previous investment of human energy (Meillassoux, 1997); this process occurs in combination with knowledge of the local factors and natural forces along with capacity and craftsmanship in the handling of work instruments (Van der Ploeg, 2018).

Nature provides a finished product (forest fruits, animal species, grasses, honey, trees, wood, etc.) over a given time, its biological time; in turn, work time, which translates into a productive activity, consists of removing the 
finished product from land. At this point, the work process is the same as the work product ${ }^{19}$; the realization of the utility of the product (from direct consumption) is also immediate. The immediacy of the work process, work product and the realization of the use value from direct consumption is one of the characteristics of this type of holdings, in which time has different conditions from those of time of capital (Paz, 2017). The other dimension related to this extractive character is associated with the noncommodification processes; indeed, there is no real need for an articulation in formal markets to obtain the basic resources for subsistence or to put the generated product in the market. Thus, the immediacy of the work process, the work product and the realization of the use as well as the presence of noncommoditization processes are synthesized by communality itself. Those dimensions are key factors so that labour, both at the family and community levels, does not lose its nature and its potential capacity as one of the central elements in reproduction and in the possible accumulation processes (Suárez \& Paz, 2017).

Besides extractive activities, agricultural and livestock production is also developed. Although agricultural production is scarce, ${ }^{20}$ there is an important livestock-pastoral activity from a production rather than extraction perspective. In this productive scheme, land is conceived as a means of work and production. Thus, the work process acquires another significance and intentionality: that of obtaining a finished product through the application of direct work in a production process, considering peasants' creativity, local knowledge and specific know-how.

It should be noted, however, that, whichever the type of work, either in the immediate process to obtain consumption goods directly or in the process oriented to obtain a product for exchange or sale in the market, both respect the vital times of nature. ${ }^{21}$ On the other hand, work time is not considered a measure of activity or social content of the product, but it does exist as a natural social good and is administered by individuals. In these holdings, rearing of small livestock (goats, sheep and pigs) and hens is usually managed by women, children and elderlies. Thus, for instance, children who spend their time looking after the herd also invest part of their time in walking around the site with pleasure, recognizing aspects of nature related to more recreational needs, setting a trap to hunt wild animals to cover their food needs or recognizing some plants that may have medicinal effects on a specific condition they or their family may have. This activity, this doing, which is typical of the human existence, exceeds the differentiation between working and not working (Holloway, 2011). As a consequence, the amount of work needed for achieving that production, measured in clock time, cannot be quantified and is consequently nonexistent. In the world of peasants, and especially in the space of AHUBs, there is no separation between work and leisure; rather, there is a time of doing oriented to diverse activities (productive, social, communal, recreational, sexual, etc.) and where, in general, as indicated by Thompson (1967), there is no feeling of conflict between working and 'spending the day'.

In general, for these holdings, the technical-social content of the used means (resources used either for consumption or production) is usually cooperative-communal, because the simultaneous and voluntary participation of several members is necessary. The need for the communal organization of some activities is essential given the context of nature itself; the history of community fields shows this phenomenon (Farberman, 2016; Palomeque, 1992). In other words, the functioning of these social and production systems in the open forest, both in the past and present, has been based on the constant and intense use of human energy both in collection ${ }^{22}$ and production processes; very often, the environmental and territorial conditions require more than the individual effort and the family environment, and activities are carried out from a communal perspective.

In short, communal systems, as thought of from the AHUB perspective, exhibit a vital and creative activity, with certain autonomy at the local level, which is restricted to those spaces, but that is constantly in tension with the

\footnotetext{
${ }^{19}$ The nature of the work product is still not adapted to a long conservation period.

${ }^{20}$ Giberti (1993) mentions a mean of 1.2 ha of established crops for these holdings, according to 1988 NCA.

${ }^{21}$ Capital rotation is the essence of the capitalist logic and, consequently, the period of capital rotation must be shortened, by reducing artificially the production time, specifically through biotechnology. Therefore, capitalist production seeks not only to reduce time to the minimum, increasing productivity, but also to shorten the 'biological excess' of time of production and of goods circulation. In this sense, vital times of nature are obstacles to development of capitalism in the agricultural sector (Mann \& Dickinson, 1978; Paz, 2017).

${ }^{22}$ For example, collection of algarrobo fruit, known as 'fruto del hambre' (hunger fruit) had a strong communal component. The 1920 National Folklore Survey recorded the 'tako pallana' festivity, in which endless caravans of people gather for harvesting algarrobo fruits (Palomeque, 1992).
} 
devastating force of the overwhelming power of capital. The strength of communal systems is based on the historical construction of communal matrices that still persist and are strongly present.

Just as haciendas (large estates) and domination systems were the factors that gave significance to rural societies and were matrices for the emergence of sociability, social integration and rebellious acts of all the society (Bengoa, 2003: 93), the history of AHUBs led to communal matrices. Those communal matrices, recognized as a productive, cultural, economic and social system, take us back to alternative forms of possession of individual private property, which were originated in the colonial period. The concept of communal matrix is used to refer to a complex set of conditions that have a basic and supportive character in the structuring of communal relationships. In the case of the rural world of Santiago del Estero, the previously mentioned processes that operated in the conformation of the agrarian structure, particularly those that led to persistence of vast land and forest areas with undefined boundaries and where occupation and appropriation modes based on common use of lands and associated resources developed over time, enabled, to some extent, the configuration of communal matrices.

This communal matrix is composed of several dimensions, and their presence and nature allow us to incorporate the notion of communal matrices as something that is dynamic and in constant movement. However, these communal matrices should be considered as processes defined by a continuous movement in several directions but always framed within a defined context. Accordingly, the first dimension is the fact of being a production system based on a nonprivate, community, collective, communal system, eliminating private property by owners and the state from production and material resources. The second dimension lies in communal work as the main production force, in which the categories of wages and profit are not present and, consequently, there is no exploitation of man or nature. The times of communal life are in cooperation and coproduction with nature and not in competition with nature; from this perspective, the theory of value is thought of from coproduction and collaboration between humans and nature as inseparable elements. The third dimension is the equitable nature in terms of distribution of and free access to goods that meet the basic needs, especially those related to production. These dimensions lead to a system of values that fosters common good, such as justice, equality, cooperation, fraternity and complementarity. This does not mean that inside these communal systems, there is a lack of conflicts and tensions, and resource use and allocation are in constant adaptation and negotiation by the dwellers present in the analysed experiences.

The other components that are discussed below denote and underline the structural conditions on which the practices of the actors are based in the configuration of communal relationships. Thus, the fourth component in this complex matrix is the availability of vast land areas, forest and other common resources. Those vast land areas are closely associated with both the high number of livestock owned by dwellers and the related practices oriented to a production based on the use of those common natural resources in a scenario with hostile agroecological and socioeconomic characteristics for the development of production forces. Finally, the fifth dimension is the mobilization of a social capital, which is understood as a complex network of social relationships that are based on collective work and the forms of appropriation of commons.

The strength of AHUBs lies in the historical construction of a communal matrix, with its diverse variants depending on the nature of its dimensions. Both experiences draw upon this potential present in the communal matrices, whose essence lies mainly in the absence of private property of land. The absorption of private property rights into a general project for collective management of commons may be an interesting approach, because it defines processes in which the central nature of capital gradually vanishes and provides opportunities for thinking of production as counter-hegemonic processes.

However, the presence of counter-hegemony does not imply that capital is not present, nor does it mean that these experiences based on AHUBs should be regarded as a return to pastoral romanticism or as a ghetto protected from all evil coming from capitalism. Capital is not hegemonic nor is totally omnipresent; for some reason in history, capital had to admit spaces in which peasant and family agriculture, as well as other subordinate groups such as indigenous peoples, still develops practices that have some independence from the reproduction of the capitalist system itself. 
Counter-hegemony is not just a construction of the autonomous political conscience in subordinate sectors: it is also innate to nature itself, as opposed to the logic of capital and which can be constructed only from the recognition of logics of subordinate groups. The organic exchange, as Marx mentions, is characterized by the fact that nature humanizes and man naturalizes. Thinking of counter-hegemony without nature implies falling in the dichotomy or in the binary opposition between market and state as having a disciplinary role of life. It also implies putting the state as a dispute area, a political arena, as the only pathway that should be necessarily coopted so that such counter-hegemonic processes can be generated; this is what Gramsci (1971) calls 'war of positions'.

A very nice metaphor by Arturo Osorio helps to understand counter-hegemonic processes as local processes within capitalism current.

The river flows. The flow hits a root of an old tree, a trunk or a stone, and forms a whirlpool, a spiral: the image of Life (...). But the whirlpool acquires its own internal dynamics, different from the river in general. However, we cannot separate the whirlpool from the river (Osorio, 2013: p. 42) (our translation).

Counter-hegemony occurs as habitual and isolated processes, as everyday strategies in social and economic practices. Nobody taught peasants to 'practice counter-hegemony'; therefore, we should not be satisfied with the idea that there are movements, groups or practices that are just hegemonic or counter-hegemonic. 'There are no sectors full-time devoted to build hegemony, others devoted to consumerism and others so aware of counter-hegemony that they live only for resistance and development of an alternative popular existence' (our translation) (Garcia Canclini, 1984).

Throughout history, AHUBs, as well as peasant and family agriculture, have shown alternative pathways to that determined by structural and determinist tendency imposed by capitalist agrarian world. Communal experiences have been revealing hidden, still unveiled experiences that, though very small, give high expectations that may become realistic and possible economic alternatives. However, capturing these counter-hegemonic processes requires conceptual frameworks and views that escape from lazy reason are necessary; otherwise, it is easy to fall in a pragmatic activism or in alternative strategies that are rapidly subsumed by capital. Perceiving AHUBs and the experiences derived from them from communal matrices may be one of those pathways.

\section{ACKNOWLEDGEMENTS}

Previous versions of this article were presented in a series of seminars within the frame of the Equipo de Sociología Rural (Rural Sociology Team), which I lead, at the Institute for Social Development Studies (INDES)/ National Scientific and Technical Research Council (CONICET). I thank the contributions and suggestions made by anonymous reviewers of the Journal of Agrarian Change and the rigorous and at the same time generous editing work of Cristóbal Kay. This research work was funded by the INDES/CONICET project PIP 11220170100056CO, Resolution -2018-8-APN-DIR\#CONICET, and by project 23/A239, funded by Scioentific and Technological Research council of the School of Agronomy and Agroindustry of the National University of Santiago del Estero (UNSE), Argentina. Finally, I thank Jorgelina Brasca for the translation of this article from Spanish into English.

\section{ORCID}

Raúl G. Paz (D) https://orcid.org/0000-0002-2809-3478

\section{REFERENCES}

Akram-Lodhi, H. (2012). Contextualising land grabbing: Contemporary land deals, the global subsistence crisis and the world food system. Canadian Journal of Development Studies, 33(2), 119-142. 
Akram-Lodhi, H., Borras, S. M. Jr., \& Kay, C. (Eds.) (2007). Land, poverty and livelihoods in an era of globalization: Perspectives from developing and transition countries. New York: Routledge.

Akram-Lodhi, H., \& Kay, C. (Eds.) (2009). Peasants and globalization: Political economy, rural transformation and the agrarian question. London and New York: Routledge.

Banzato, G., \& Rossi, M. (2010). El mercado de tierras en las fronteras interiores argentinas: la expansión territorial de Buenos Aires y Santiago del Estero en la segunda mitad del siglo XIX. América Latina en la Historia Económica, 34, 7-34.

Barbetta, P. (2009). En los bordes de lo jurídico. Conflictos por la tenencia legal de la tierra en Santiago del Estero. Unpublished PhD thesis. Universidad de Buenos Aires.

Beltrán Tapia, F. (2014). Social and environmental filters to market incentives: The persistence of common land in nineteenth-century Spain. Journal of Agrarian Change, 15(2), 239-260.

Bengoa, J. (2003). 25 años de studios rurales. Sociologia, 5(10), 36-98.

Boltvinik, J., \& Mann, S. (2016). Peasant poverty and persistence in the twenty first century: Theories, debates, realities and policies. London: Zed Books.

Borras, S. Jr., \& Franco, J. (2010). La política del acaparamiento mundial de tierras: replanteando las cuestiones de tierras, redefiniendo la resistencia. In ICAS Working Paper Series 001, published by Land Deal Politics Initiative (LDPI) and Transnational Institute (TNI).

Borras, S., \& Franco, J. (2012). Global land grabbing and trajectories of agrarian change: A preliminary analysis. Journal of Agrarian Change, 12(1), 34-59.

Borras, S., Kay, C., Gómez, S., \& Wilkinson, J. (2012). Land grabbing and global capitalist accumulation: Key features in Latin America. Canadian Journal of Development Studies, 33(4), 402-416.

Cáceres, D. (2015). Accumulation by dispossession and socio-environmental conflicts caused by the expansion of agribusiness in Argentina. Journal of Agrarian Change, 15(1), 116-147.

Camardelli, C. (2005). Estrategias reproductivas y sustentabilidad de sistemas ganaderos criollos del Chaco salteño: el caso de los puesteros criollos del lote fiscal $\mathrm{n}^{\circ} 20$ en el departamento Rivadavia. Revista Interdisciplinaria de Estudios Agrarios, 22, 32-57.

Caracciolo Basco, M., \& Rodríguez Sánchez, C. (1978). El minifundio en la Argentina. Primera parte. Grupo Sociología Rural. Buenos Aires: Secretaría de Estado de Agricultura y Ganadería.

Craviotti, C., \& Gras, C. (2006). De desafiliaciones y desligamientos: Trayectorias de productores familiares expulsados de la agricultura pampeana. Desarrollo Económico, 181, 117-134.

Dargoltz, R. (2003). Hacha y Quebracho. Historia ecológica y Social de Santiago del Estero. Santiago del Estero: Vizzoso.

De Dios, R. (2012). Ordenamiento territorial e inclusión social en Santiago del Estero. Revista Realidad Económica, 268, 115-127.

Diaz Habra, H., \& Jara, C. (2018). La construcción de un espacio protegido mediante el contracercamiento de los bienes comunes. El diseño de la Reserva Campesina en las Serranías de Ambargasta. In R. Paz, R. Rodriguez, \& C. Jara (Eds.), Sistemas comunales y explotaciones sin límites definidos. Persistencia del campesinado en Argentina (pp. 63-107). Santiago del Estero: EDUNSE.

Farberman, J. (2016). Las tierras mancomunadas en Santiago del Estero. Problemas y estudios de caso en la colonia y el siglo XIX. Mundo Agrario, 17(36), 1-25.

Farberman, J. (2018). Dueños, agregados, derechos de propiedad y matrices comunales en Santiago del Estero. Una aproximación histórica. In R. Paz, R. Rodriguez, \& C. Jara (Eds.), Sistemas comunales y explotaciones sin límites definidos. Persistencia del campesinado en Argentina (pp. 63-107). Santiago del Estero: EDUNSE.

Fazio, L. (1889). Memoria histórica y descriptiva de la provincia de Santiago del Estero. Buenos Aires: Compañía Impresora de Billetes de Banco

Garcia Canclini, N. (1984). Cultura y organización popular. Gramsci con Bourdieu. Cuadernos Políticos, 38, 75-82. México: Era.

García Linera, Á. (2010). La forma comunidad del proceso de producción. Formas comunales que han precedido al régimen del capital: Algunas determinaciones de forma y contenido técnico-organizativo. Buenos Aires: Prometeo/CLACSO.

Giberti, H. (1993). Cambios en las estructuras agrarias. Realidad Económica, 113, 87-89.

Gómez, A., Jara, C., Díaz Habra, H., \& Villalba, A. (2018). Contracercar, producir y resistir. La defensa de los bienes comunes en dos comunidades campesinas (Argentina). Revista Eutopía, 13, 137-155.

Gómez, A., Villalba, A., \& Tort, J. (2018). Comunalidades en el espacio rural, una mirada desde las prácticas. Experiencias de encierros comunitarios y ganaderos en Santiago del Estero. In R. Paz, R. Rodriguez, \& C. Jara (Eds.), Sistemas comunales y explotaciones sin límites definidos. Persistencia del campesinado en Argentina (pp. 181-233). Santiago del Estero: EDUNSE.

González, M. (2000). Argentina, situaciones problemáticas de tenencia de la tierra. Serie Documentos de formulación PROINDER. Buenos Aires: SAGyP.

Gramsci, A. (1971). Selections from the prison notebooks. New York: International Publishers. 
Gras, C. (2009). Changing patterns in family farming: The case of the Pampa Region, Argentina. Journal of Agrarian Change, 9(3), 345-364.

Harvey, D. (2005). El nuevo imperialismo: acumulación por desposesión. Buenos Aires: CLACSO.

Harvey, D. (2014). Diecisiete contradicciones y el fin del capitalismo. Madrid: Traficantes de sueños.

Holloway, J. (2011). Agrietar el capitalismo. El hacer contra el trabajo. Buenos Aires: Herramienta.

Lapegna, P. (2018). La economía política del boom agro-exportador bajo los Kirchner: Hegemonía y revolución pasiva en Argentina. In C. Kay, \& L. Vergara-Camus (Eds.), La cuestión agraria y los gobiernos de izquierda en América Latina. Campesinos, agronegocios y neodesarrollismo (pp. 155-189). Buenos Aires: CLACSO.

Linsalata, L., \& Navarro, M. (2014). Feminismo y alternativas no capitalistas para la reproducción de la vida. Claves para repensar lo común. Entrevista a Silvia Federici. In Composto, C y Navarro, M (Compiladores.). In Territorios en disputa. Despojo capitalista, luchas en defensa de los bienes comunes naturales y alternativas emancipatorias para América Latina (pp. 425-438). México: Bajo Tierra Ediciones.

Mann, S., \& Dickinson, J. (1978). Obstacles to the development of a capitalist agriculture. The Journal of Peasant Studies, 5(4), 466-481. London: Routledge

Manzanal, M. (1995). Globalización y ajuste en la realidad regional argentina: ¿Reestructuración o difusión de la pobreza? Realidad Económica, 134, 67-82. Argentina: IADE

Mariot, V. (2005). Bases para el ordenamiento del uso de la tierra. En Santiago del Estero. Una mirada ambiental. Santiago del Estero: UNSE-Facultad de Ciencias Forestales.

Marx, K., \& Hobsbawm, E. (1987). Formaciones económicas precapitalistas. México: Siglo XXI.

Marx, K. (1984). El Capital. Argentina: Orbis.

McMichael, P. (2013). Land grabbing as security mercantilism in international relations. Globalizations, 10(1), 47-64.

Meillassoux, C. (1997). Mujeres, graneros y capitales. Madrid: Ed. Siglo XXI.

Obschatko, E., Foti, M., \& Román, M. (2007). Los pequeños productores en la República Argentina. Importancia en la producción agropecuaria y en el empleo en base al CNA 2002. Buenos Aires: IICA.

Osorio, A. (2013). La comunalidad como herramienta: Una metáfora espiral. Cuaderno del Sur, 34, 39-55.

Palomeque, S. (1992). Los esteros de Santiago. Acceso a los recursos y participación mercantil: Santiago del Estero en la primera mitad del siglo XIX. Data. Revista del Instituto de Estudios Andinos y Amazónicos, 2, 9-61.

Patzi Paco, F. (2004). Sistema comunal. Una propuesta alternativa al sistema liberal. La Paz: CEA.

Paz, R. (2006). ¿Desaparición o permanencia de los campesinos ocupantes en el Noroeste Argentino? Evolución y crecimiento en la última década. Canadian Journal of Latin American and Caribbean Studies, 31(61), 169-197.

Paz, R. (2011). Agricultura familiar y procesos de transformación en el agro argentino: Una contribución al debate sobre el futuro del campesinado. Revista Europea de Estudios Latinoamericanos y del Caribe, 91, 49-70.

Paz, R. (2013). Explotaciones sin límites definidos y desarrollo rural en Santiago del Estero: Hacia un ordenamiento. Realidad Económica, 277, 109-128. Buenos Aires: IADE.

Paz, R., \& Jara, C. (2013). Las nuevas dinámicas de los antiguos conflictos de tierra en regiones extrapampeanas. Revista Fenix, 27, 33-43.

Paz, R. (2017). Las grietas de los agronegocios y los imperativos de la agricultura familiar: Hacia una perspectiva conceptual. Revista Latinoamericana de Estudios Rurales, 2(3), 39-63.

Paz, R., \& Jara, C. (2014). Censos y registros de la agricultura familiar en Argentina: Esfuerzos para su cuantificación. Revista Eutopía, 6, 75-91.

Paz, R., Jara, C., \& Wald, N. (2019). Tensions around land tenure in Argentina's agrarian periphery: Scales and multiple temporalities of capitalism in Santiago del Estero, Argentina. Latin American Research Review, 54, 1-13.

Paz, R., Lipshitz, H., Zerda, R., \& Tiedeman, J. (2015). Estructura agraria, áreas de concentración de la agricultura familiar y procesos de expansión de la frontera agropecuaria en Santiago del Estero, Argentina. Revista NERA, 27, $259-279$.

Paz, R., Rodríguez, R., \& Jara, C. (2018). Sistemas comunales y explotaciones sin límites definidos. In Persistencia del campesinado en Argentina. Santiago del Estero: EDUNSE.

Peluso, N., \& Lund, C. (2011). New frontiers of land control: Introduction. Journal of Peasant Studies, 38(4), 667-681. London: Routledge

Polanyi, K. (2011). La gran transformación. Mexico: Fondo de la Cultura Económica.

Román, M., \& González, M. (2016). Tansformaciones agrarias argentinas durante las últimas décadas. Una visión desde Santiago del Estero y Buenos Aires. Buenos Aires: Facultad de Agronomía. UBA.

Santos de Sousa, B. (2006). Renovar la teoría crítica y reinventar la emancipación social. Buenos Aires: CLACSO.

Santos de Sousa, B., \& Rodríguez, C. (2011). Para ampliar el canon de la producción. In B. Santos de Sousa, B (coord.). In Producir para vivir. Los caminos de la producción no capitalista (pp. 15-61). México: Fondo de Cultura Económica.

Slutzky, D. (2007). Situaciones problemáticas de tenencia de la tierra en Argentina. Serie de Estudios e Investigaciones $N{ }^{\circ} 14$, Documentos PROINDER. Buenos Aires: SAGyP.

Smith, A. (1997). Investigación sobre la naturaleza y causas de la riqueza de las naciones. México: Fondo de Cultura Económica. 
Soto Baquero, F., \& Gómez, S. (2012). Dinámicas del Mercado de la Tierra en América Latina y el Caribe: Concentración y Extranjerización. Rome: FAO.

Suárez, V., \& Paz, R. (2017). Pensando los procesos de acumulación en sistemas comunales: desarrollo de las fuerzas productivas, innovaciones tecnológicas y Estado. El caso de Colonia Jaime, Argentina. Revista Eutopía, 11, 97-112.

Tasso, A. (2005). Vida humana y organización social en condiciones de escasez. En Santiago del Estero, una mirada ambiental. Santiago del Estero: UNSE-Facultad de Ciencias Forestales.

Thompson, E. (1967). Tiempo, disciplina de trabajo y capitalismo industrial. En Tradición, revuelta y conciencia de clase. Estudios sobre la crisis de la sociedad preindustrial. Barcelona: Crítica.

Van Der Ploeg, J. (2018). The new peasantries. Rural development in times of globalization. London: Routledge.

Wald, N. (2016). Historical paths to current unrest: Extending the temporal lens in analysing geographies of agrarian change and conflicto. Geoforum, 76, 38-47.

Wood, E. (2002). The question of market dependence. Journal of Agrarian Change, 2(1), 50-87.

Wood, E. (2009). Peasants and the market imperative: The origins of capitalism. In H. Akram-Lodhi, \& C. Kay (Eds.), Peasants and Globalization (pp. 57-82). London: Routledge.

How to cite this article: Paz RG. Agricultural holdings with undefined boundaries, communal systems and counter-hegemonies: The persistence of peasantry in Argentina. J Agrar Change. 2020;1-17. https://doi.org/ 10.1111/joac.12363 